\title{
Editorial
}

\section{7th International Wildland Fire Conference}

\author{
Lara Steil - Ibama/Prevfogo \\ Luciana de Oliveira Rosa Machado - MMA
}

This Special Issue is the third publication related to the 7th International Wildland Fire Conference - IWFC, held in 2019, in Brazil (https://www.ibama.gov.br/wildfire2019-eng). It comprises full articles written by the key speakers who participated at the Plenary Sessions, Special Sessions, and at the Technical Meeting on Criminal Investigation of Forest Fires.

The opening article, by Johann Goldammer, presents a retrospective on the series of IWF Conferences, from its first edition, held in Boston, USA, in 1989, until the seventh, in Brazil, after a circumglobal journey. The main advances and achievements along the three decades that separate these two Conferences are discussed, emphasizing the changes observed in the fire regimes around the world, influenced by world population growth, socioeconomic developments, and climate change, pointing out the importance of international cooperation for landscape fire management.

The role of women in fire management, one original topic at 7th IWFC, is brought to discussion by Erika Garduño-Mendoza and collaborators. The article summarizes the main achievements, challenges, and experiences related to the inclusion of women in fire management activities in Mexico and Latin America. According to the authors, the efforts that have been carried out on this issue led to the creation of the first female brigade for preventing and fighting fires in Mexico, in 2019. The strengthening of women's technical and leadership capacities gives more visibility to their participation, reinforces the integrated fire management approach, and opens up new opportunities for professionals with different profiles and areas of knowledge.

In the same track of inclusion and improvement of the participation of human diversity in fire issues, John Scott, in his article, reviews the importance of indigenous knowledge on disaster risk reduction, flagging up that this knowledge has been used to reduce risks and mitigate the deleterious effects caused by uncontrolled fires. The article also draws our attention to the fact that when traditional practices are associated with contemporary experiences, they can reduce the vulnerability of these peoples and their communities to the risks arising from fire.

Four articles discuss, on a national or local scale, the implementation of integrated fire management in Brazil. In the first one, Background, Assessment, Opportunities and Challenges of Integrated Fire Management in Brazilian Indigenous Land, Rodrigo Falleiro and collaborators present the main outcomes of the implementation of the Federal Brigade Program in indigenous lands. The program is handled by the Brazilian Institute for the Environment and Renewable Natural Resources, through the National Center for Preventing and Fighting Fire (Ibama/Prevfogo) in partnership with the National Indian Foundation (Funai). The results demonstrate that the incorporation of traditional indigenous knowledge in the implementation of Integrated Fire Management (IFM) represents the factor of success to address the issue, emphasizing the importance of the sociocultural aspect in the management of fire in Brazil. 
The article Implementation of Integrated Fire Management in Brazilian Federal Protected Areas: Results and Perspectives developed by Berlinck \& Lima, presents the main achievements and challenges in Brazilian protected areas that adopted IFM approach. Among them, the reduction of the area affected by uncontrolled fires and the conciliation of conflicts with communities living in or around the protected areas stand out. The text addresses in more detail three protected areas: Serra da Canastra National Park, Serra Geral do Tocantins Ecological Station and the Campos Amazonicos National Park, revealing positive examples of integration among government, researchers, and society.

Ana Carolina Barradas et al. - Integrated fire management: Serra Geral do Tocantins Ecological Station's journey (2001 to 2020) - and Pedro Paulo Xerente et al. - Indigenous Approach to Integrated Fire Management in Indigenous Lands in the State of Tocantins/ Brazil - show in detail how the paradigm shift from fire exclusion to the adoption of integrated fire management took place in two important Brazilian protected areas. The experiences of these areas highlight how fire can be used as a tool for participatory management and conservation of Brazilian socio-biodiversity. In addition to contributing to the empowerment of knowledge and the traditional use of fire by indigenous peoples and traditional communities.

Other experiences of integrated fire management are presented in the article Marketbased Options for Supporting Sustainable Fire Management of Fire-prone Cerrado (Savanna) Remnant Landscapes by Russell-Smith et al. The authors illustrate the potential of economic and market tools of integrated fire management programs implemented in the savannas of Australia and Botswana, outlining the need and opportunity for developing an analogous fire management approach in Brazilian Cerrado, especially in indigenous lands. This paper is a summary of the discussions carried out at a Special Session on the same theme, held during the 7th IWFC.

Turning to technological aspects of fire management, the paper Remote Sensing and Geoprocessing as a Subsidy for Fire Management and Fighting Forest Fires in Federal Conservation Units (Kelly Resende Borges et al.) presents the importance of remote sensing and geoprocessing for environmental conservation and monitoring of environmental impacts caused by fires. The article underlines the elaboration of fuel load maps, which joint with the mapping of areas affected by fire, constitute a fundamental tool for planning and managing large territories, as is the case of most of the Brazilian protected areas. These geotechnologies identify the most prone areas to fire, the frequency of fire occurrence, indicating strategies to minimize damages in the most critical areas.

The gas emissions from landscape fires contribute to climate change and affect human health and security. In this regard, Alexander Baklanov et al. come up with the Vegetation Fire and Smoke Pollution Warning Advisory and Assessment System (VFSP-WAS) to provide guidance for addressing both smoke and fire danger. The paper also proposes the establishment of regional VFSP-WAS centers and shows potential examples of the VFSPWAS concept in two regions (Southeast Asia and North America), where regional VFSPWAS centers work in partnership with Regional Fire Monitoring/Fire Management Resource Centers.

More details of the Southeast Asia VSP-WAS example are presented in this edition by Saharjo et al., whose studies indicate that the increase in fires has caused serious threats to forests and to the health and safety of the populations of that region. The focus of the article is the peat fire, a quite common event in that region, particularly in Indonesia, which holds $36 \%$ of the world's tropical peatland. Peat fires are considered one of the most difficult types of fires to control. In addition, they are one of the main causes of environmental degradation and air pollution, being responsible for the emission of considerable amounts of $\mathrm{CO}_{2}$ and other greenhouse gases, as well as particulate matter that causes serious damage to human health. 
We end this publication with another original topic for this series of Conferences brought by the 7th IWFC. A technical meeting on the Criminal Investigation of Forest Fires was held at the Conference and the results of it are presented in Salvador Ortega's article. The paper addresses the growing need to include a criminal investigation of forest fires to establish effective preventive measures and to identify and punish who causes major forest fires. Therefore, it is necessary to improve the judgment processes by the justice bodies and inspection agencies that deal with such conduct, which is considered a crime in the criminal regulations of most, if not all, of the countries on the planet. The study describes the efforts of INTERPOL to contribute to the harmonization and improvement of criminal investigation processes worldwide and the development of training tools at the international level.

This special issue aims to contribute to spreading the experiences on fire management in different parts of the world. We hope the papers presented here can encourage the international fire community to keep strengthening the global debate on fire issues while looking forward to the next International Wildland Fire Conference in 2023, in Portugal.

\section{Biodiversidade Brasileira - BioBrasil. \\ Edição Temática: 7th International Wildland Fire Conference \\ n. 2, 2021 \\ http://www.icmbio.gov.br/revistaeletronica/index.php/BioBR}

Biodiversidade Brasileira é uma publicação eletrônica científica do Instituto Chico Mendes de

Conservação da Biodiversidade (ICMBio) que tem como objetivo fomentar a discussão e a disseminação de experiências em conservação e manejo, com foco em unidades de conservação $e$ espécies ameaçadas.

ISSN: 2236-2886 